\title{
PRIORITAS RISIKO PENANGANAN DAN TRANSPORTASI IKAN TUNA DI PELABUHAN PERIKANAN PANTAI (PPP) PONDOKDADAP
}

\author{
Risk Priority of Handling and Transportation of Tuna at Pelabuhan Perikanan Pantai (PPP) \\ Pondokdadap \\ Oleh: \\ Nymas Sidratus Sakina ${ }^{1}$, Fis Purwangka ${ }^{2 *}$, Mustaruddin ${ }^{2}$ \\ ${ }^{1}$ Program Studi Teknologi Perikanan Laut Pascasarjana IPB, \\ Bogor, Indonesia \\ ${ }^{2}$ Departemen Pemanfaatan Sumberdaya Perikanan FPIK- \\ IPB, Bogor, Indonesia \\ *Korespondensi penulis: fis@psp-ipb.org
}

\begin{abstract}
ABSTRAK
Ikan tuna (Thunnus sp) merupakan sumberdaya perikanan dan kelautan di Indonesia yang mempunyai nilai ekonomis tinggi dalam jumlah besar. Salah satu sentra produksi tuna berada di Provinsi Jawa Timur tepatnya di Pelabuhan Perikanan Pantai (PPP) Pondokdadap, Kabupaten Malang. Kualitas ikan tuna di PPP Pondokdadap sebagian besar memiliki kualitas sedang (grade B) dan tidak sedikit pula yang memiliki kualitas $C$ dan $D$. Hal ini terjadi karena fasilitas penanganan yang kurang memadai dan kurangnya pengetahuan para pelaku usaha bahwa dalam setiap kegiatan penanganan dan transportasi yang kurang baik terdapat risiko yang mengakibatkan terjadinya penurunan mutu sehingga nilai jualnya kurang maksimal. Tujuan penelitian ini yaitu mengidentifikasi dan memetakan risiko prioritas dalam aktivitas penanganan dan transportasi ikan tuna di PPP Pondokdadap dengan pendekatan FMEA. Sehingga didapatkan risiko kritis dan harus segera dilakukan pengembangan mitigasi pada perikanan tuna di PPP Pondokdadap. Penelitian dilaksanakan pada bulan November 2020. Metode pengumpulan data menggunakan metode wawancara dan observasi langsung. Hasil yang diperoleh bahwa penurunan mutu terbesar berada pada spesies tuna albakor dengan berat $220 \mathrm{~kg}$. Terdapat 4 mode kegagalan (failure mode) yang menjadi risiko prioritas dalam penurunan mutu selama penanganan dan transportasi ikan tuna albakor $\geq 20 \mathrm{~kg}$ di PPP Pondokdadap. Mode kegagalan tersebut yaitu pencucian ikan dengan air kotor, ikan dilempar saat penyortiran, ikan diletakkan di lantai tanpa alas dan penggunaan moda transportasi dengan mobil bak terbuka.
\end{abstract}

Kata kunci: Albakor, FMEA, penanganan, pondokdadap, risiko, transportasi

\section{ABSTRACT}

Tuna (Thunnus $s p$ ) is a fishery and marine resource in Indonesia that has high economic value in large quantities. One of the centers of tuna production is in East Java Province, namely at PPP Pondokdadap, Malang Regency. The quality of tuna in PPP Pondokdadap is mostly of medium quality (grade B) and many have $C$ and $D$ quality. This condition occurs due to bad handling facilities and lack of knowledge of business actors that in every handling and transportation activity there are risks. It has the impact of a decrease in quality so that the selling value is less than the maximum. This research aims to identify and determine of priority risk in handling and transportation activities of tuna at PPP Pondokdadap using the FMEA approach. So that mitigation for the critical risk of tuna fisheries in Pondokdadap can be developed. The research was held in November 2020. The method of data collection used interview and direct observation. The result was explained that the largest quality loss of tuna is albacore with weight $\geq 20 \mathrm{~kg}$. There are 4 failure modes that become priority risks in quality degradation during handling and transportation of $220 \mathrm{~kg}$ albacore tuna at PPP Pondokdadap. The 
failure modes are washing fish with dirty water, throwing fish during sorting, putting fish on the floor without a mat and using a pickup truck.

Key words: Albacore, FMEA, handling, Pondokdadap, risk, transportation

\section{PENDAHULUAN}

Ikan tuna (Thunnus sp) merupakan sumberdaya perikanan dan kelautan di Indonesia yang mempunyai nilai ekonomis tinggi dalam jumlah besar (Yusra et al. 2014). Salah satu sentra produksi tuna berada di Provinsi Jawa Timur tepatnya di PPP Pondokdadap, Kabupaten Malang. Pada tahun 2020 produksi ikan tuna di PPP Pondokdadap sebesar 1231 ton dan untuk lima tahun terakhir (tahun 2016 sampai 2020) volume tuna yang didaratkan sebesar 7.653 ton (PPP Pondokdadap 2020). Hasil tangkapan tuna (Thunnus sp) yang didaratkan di PPP Pondokdadap dipasarkan ke perusahaan pengekspor dan pasar lokal yang berada di Malang, Probolinggo dan Lamongan. Harga jual ikan tuna standar ekspor ditingkat nelayan sebesar Rp55.000 per kg, sedangkan harga tuna yang akan dipasarkan secara lokal berkisar antara Rp18.000 sampai Rp25.000 per kg. Nurani (2010) mengatakan bahwa harga ikan tuna akan saling terkait dengan kualitas yang ada.

Kualitas ikan tuna di PPP Pondokdadap sebagian besar memiliki kualitas sedang (grade B) dan tidak sedikit pula yang memiliki kualitas $C$ dan D. Hal ini terjadi karena beberapa faktor, diantaranya fasilitas penanganan yang kurang memadai dan kurangnya pengetahuan para pelaku usaha bahwa dalam setiap kegiatan penanganan dan transportasi yang kurang baik terdapat aktivitas risiko yang mengakibatkan terjadinya penurunan mutu. Furqan (2017) menjelaskan, bahwa penanganan dan kendaraan yang digunakan pelaku usaha dalam distribusi ikan tuna di PPP Pondokdadap terdiri dari 2 unit kontainer berpendingin dan 17 unit truk terbuka. Kontainer berpendingin akan digunakan untuk ikan tuna dengan tujuan ekspor dan truk terbuka akan digunakan untuk tuna tujuan pasar lokal.

Hasil survei awal yang dilakukan oleh peneliti didapatkan bahwa hal ini berdampak pada penurunan mutu yang signifikan dan $79 \%$ hasil tangkapan ikan tuna hanya dapat dipasarkan ke pasar domestik dengan harga yang murah. Syafitri et al. (2016) menjelaskan bahwa penurunan mutu ikan akan diikuti penurunan harga pada setiap segmen pasar. Besarnya prosentase tuna yang masuk ke pasar domestik menyebabkan banyak tuna yang tidak mendapat pasar dengan cepat, sehingga semakin banyak tuna yang mengalami penurunan mutu dan berdampak pada daya beli konsumen. Seperti halnya pada penelitian Tunjungsari (2009) yang menyatakan bahwa konsumen akan cenderung memilih ikan segar yang diperhatikan melalui warna, mata dan tekstur dalam membeli ikan yang akan dikonsumsi.

KEPMEN-KP 52A/2013 tentang Persyaratan Jaminan Mutu dan Keamanan Hasil Perikanan pada Proses Produksi, Pengolahan dan Distribusi merupakan standar acuan dalam menangani produk perikanan. Peraturan tersebut memuat hal-hal yang berkaitan dengan jaminan mutu dan keamanan produk perikanan termasuk didalamnya yaitu fasilitas, peralatan, transportasi dan cara penanganan. Dalam praktiknya, PPP Pondokdadap telah berupaya untuk memenuhi standar penanganan dan transportasi yang telah ditetapkan. Namun karena banyaknya faktor yang menyebabkan turunnya mutu dan harga jual tuna yang rendah, PPP Pondokdadap dan pelaku usaha kesulitan dalam menentukan risiko prioritas yang harus lebih dulu diperhatikan selama penanganan dan transportasi ikan tuna. Risiko merupakan kemungkinan kejadian yang berpotensi merugikan atau suatu keadaan yang tidak pasti yang dapat memberikan dampak yang merugikan bagi seseorang atau perusahaan (Purwitasari 2011). Oleh karena itu, analisis risiko penting dilakukan dalam kegiatan usaha untuk mencegah atau menghindari terjadinya kerugian.

Upaya untuk mengurangi dampak terjadinya kerugian dari perikanan tuna di Pondokdadap salah satunya dengan cara melakukan identifikasi risiko. Hal ini bertujuan untuk menguraikan dan merinci jenis risiko yang mungkin terjadi pada aktivitas penanganan dan transportasi ikan tuna, 
sehingga didapatkan prioritas risiko yang harus ditangani terlebih dahulu (Perdana dan Yuliawati 2014). Tujuan penelitian ini yaitu mengidentifikasi dan memetakan risiko prioritas dalam aktivitas penanganan dan transportasi ikan tuna di PPP Pondokdadap.

\section{METODE PENELITIAN}

Penelitian ini dilaksanakan pada bulan November 2020. Aspek yang diteliti dalam penelitian ini adalah risiko aktivitas penanganan dan transportasi ikan tuna di Pelabuhan Perikanan Pantai (PPP) Pondokdadap, Kabupaten Malang. Metode pengumpulan data menggunakan metode wawancara dengan panduan kuesioner dan pengamatan langsung di lapangan. Teknik pengambilan sampel ikan dalam pengukuran mutu akan dilakukan pada setiap rantai logistik mulai dari penangkapan dengan hand line sampai ke konsumen secara accidental sampling. Teknik penentuan responden dalam wawancara menggunakan metode purposive sampling. Analisis data yang digunakan dalam penelitian ini yaitu analisis sensori, peta kendali p, diagram Fishbone, Risk Assesment dan Risk Priority Number (RPN) dengan pendekatan Failure Mode And Effect (FMEA).

\section{Analisis Sensori}

Analisis sensori adalah metode yang digunakan untuk mengevaluasi mutu secara subjektif dengan melakukan pengamatan pada bagian tubuh ikan yang dapat dijadikan sebagai indikator kesegaran, seperti mata, insang, daging atau perut, dan konsistensi. Contoh metode sensori adalah uji organoleptik (Laismina et al. 2014). Pada penelitian ini, uji organoleptik digunakan untuk mengetahui tingkat mutu dan penurunan mutu yang terjadi pada tuna (Thunnus sp) di setiap rantai logistik sampai dengan konsumen. Rantai logistik ini akan dibedakan berdasar alat tangkap yang digunakan dalam penangkapan tuna di PPP Pondokdadap, yaitu hand line.

Penilaian mutu dengan pengamatan organoleptik akan dilakukan dengan uji skor. Pengambilan skor dilakukan dengan menggunakan score sheet yang telah ditetapkan oleh Badan Standarisasi Nasional dengan SNI 01-2729.1-2006 dengan parameter penampakkan luar, kelenturan daging, keadaan mata, daging perut, bau, serta warna insang. Nilai yang dapat diberikan pada score sheet bergantung pada kondisi setiap parameter sampel. Setiap parameter akan diberi nilai berkisar antara 19 dengan nilai 1 untuk kondisi paling buruk dan nilai 9 untuk kondisi paling baik sesuai dengan deskripsi yang ada pada panduan SNI 01-2729.1-2006. Data yang diperoleh dari lembar penilaian selanjutnya akan ditabulasi dan ditentukan nilai mutunya dengan rata-rata yang diperoleh pada setiap sampel ikan.

\section{Analisis Peta Kendali p}

Peta kendali merupakan alat yang secara grafis digunakan untuk memonitor dan mengevaluasi apakah suatu aktivitas/proses berada dalam pengendalian kualitas secara statistika atau tidak sehingga dapat memecahkan masalah dan menghasilkan perbaikan kualitas (Arsyad et al. 2017). Peta kendali yang akan digunakan pada penelitian ini adalah peta kendali $\mathrm{p}$ (pengendali proporsi kesalahan dalam $\%)$. Peta kendali p berfungsi untuk memonitor konsistensi mutu ikan tuna pada setiap rantai logistik mulai dari aktivitas penangkapan hingga pemasaran berdasarkan data mutu sebelumnya (data organolepotik). Manfaat dari peta kendali p untuk membantu pengendalian mutu, memberi informasi apakah produk masih dalam atau sudah di luar pengendalian, serta kapan dan dimana produsen harus melakukan perbaikan kualitas (Khomah dan Rahayu 2015). Adapun pembuatan peta kendali $\mathrm{p}$ dilakukan dengan tahap-tahap sebagai berikut:

1. Menghitung proporsi ketidaksesuaian

Proporsi ketidaksesuaian digunakan untuk melihat seberapa besar proporsi kerusakan ikan yang terjadi pada tiap sub-group (proses). Rumus yang digunakan adalah sebagai berikut:

$$
\mathrm{p}=\frac{\mathrm{np}}{\mathrm{n}}
$$


Keterangan:

$\mathrm{p}=$ proporsi ketidaksesuaian

$\mathrm{np}=$ jumlah ketidaksesuaian dalam sub-grup (proses)

$\mathrm{n}$ = jumlah sampel yang diperiksa dalam sub-grup (proses)

2. Menghitung garis pusat (center line)

Garis pusat merupakan rata-rata ketidaksesuaian ikan (p)

$$
\mathrm{CL}=\overline{\mathrm{p}}=\frac{\sum \mathrm{np}}{\sum \mathrm{n}}
$$

Keterangan:

$\mathrm{CL}=$ center line

$\sum \mathrm{np}=$ jumlah total ketidaksesuaian

$\sum \mathrm{n}=$ jumlah total sampel yang diamati

3. Menghitung batas kendali atas (Upper control limit = UCL)

$$
\mathrm{UCL}=\overline{\mathrm{p}}+3 \sqrt{\frac{\overline{\mathrm{p}}(1-\overline{\mathrm{p}})}{n}}
$$

Keterangan:

$\mathrm{UCL}=$ Upper control limit;

$\overline{\mathrm{p}} \quad$ = rata-rata ketidaksesuaian produk

$\mathrm{n} \quad=$ jumlah sampel tiap proses

4. Menghitung batas kendali bawah (Lower control limit = LCL)

$$
\mathrm{LCL}=\overline{\mathrm{p}}-3 \sqrt{\frac{\overline{\mathrm{p}}(1-\overline{\mathrm{p}})}{n}}
$$

Keterangan:

$$
\begin{aligned}
& \mathrm{LCL}=\text { Lower control limit } \\
& \overline{\mathrm{p}} \quad=\text { rata-rata ketidaksesuaian produk } \\
& \mathrm{n} \quad=\text { jumlah sampel tiap proses }
\end{aligned}
$$

\section{Diagram Sebab-Akibat/Fishbone Diagram}

Diagram tulang ikan atau fishbone diagram adalah salah satu metode untuk menganalisis penyebab dari sebuah masalah atau kondisi (Rahmah 2010). Sering juga diagram ini disebut dengan diagram sebab-akibat atau cause effect diagram. Analisis fishbone diagram dalam penelitian ini menggunakan konsep 4M (material, method, man, dan machine) sesuai dengan pernyataan Murnawan dan Mustofa (2014) bahwa dalam diagram fishbone terdapat 4 faktor yang menjadi penyebab dari suatu masalah, yaitu man, machine, material dan method. Diagram ini berguna dalam mengidentifikasi secara tepat hal-hal yang berpengaruh terhadap mutu hasil tangkapan tuna (Thunnus sp), khususnya penurunan mutu akibat dari aspek penanganan dan transportasi.

\section{Risk Assesment}

Risk assessment (penilaian risiko) adalah metode yang sistematis untuk menentukan apakah suatu organisasi memiliki risiko yang dapat diterima atau tidak. Melalui pendekatan FMEA, penelitian ini akan menghitung tingkat severity, occurrence dan detection (Andiyanto et al. 2017). Kartikasari dan Romadhon (2019) menjelaskan bahwa tingkat kerusakan (severity) adalah penilaian seberapa serius kerusakan yang dihasilkan karena terjadi kegagalan proses terhadap mutu saat penanganan dan transportasi tuna. Nilai frekuensi (occurrence) ditentukan dengan melihat seberapa banyak gangguan yang menyebabkan kegagalan pada penanganan dan transportasi tuna dalam mempertahankan mutu. Tingkat Deteksi (detection) adalah melihat bagaimana kegagalan tersebut dapat diketahui sebelum terjadi. Adapun kriteria dalam menentukan nilai SOD adalah sebagai berikut: 
Tabel 1 Penilaian tingkat kerusakan, frekuensi kejadian dan tingkat deteksi

\begin{tabular}{|c|c|c|c|}
\hline \multirow{2}{*}{ Skala } & \multicolumn{3}{|c|}{ Deskripsi Risiko* } \\
\hline & Tingkat Kerusakan (S) & 1ensi Kejadian $(\mathrm{O})$ & Tingkat deteksi(D) \\
\hline 1 & $\begin{array}{l}\text { - } \quad \text { kerusakan dapat diabaikan } \\
\text { - } \quad \text { konsumen tidak memperhatikan } \\
\text { kecacatan }\end{array}$ & $\begin{array}{l}\text { terjadi } 1 \text { pada tiap } 10 \text { kali } \\
\text { dilakukan aktivitas }\end{array}$ & $\begin{array}{l}\text { dapat dideteksi } \\
\text { dengan mudah }\end{array}$ \\
\hline 2 & $\begin{array}{l}\text { - } \quad \text { kerusakan ringan } \\
\text { - } \quad \text { konsumen tidak merasakan penurunan } \\
\text { kualitas }\end{array}$ & $\begin{array}{l}\text { terjadi } 1 \text { pada tiap } 7 \text { kali } \\
\text { dilakukan aktivitas }\end{array}$ & $\begin{array}{l}\text { peluang terdeteksi } \\
\text { tinggi }\end{array}$ \\
\hline 3 & $\begin{array}{ll}\text { - } & \text { kerusakan sedang } \\
\text { - } & \text { konsumen merasakan penurunan } \\
& \text { kualitas namun masih dalam toleransi }\end{array}$ & $\begin{array}{l}\text { terjadi } 1 \text { pada tiap } 5 \text { kali } \\
\text { dilakukan aktivitas }\end{array}$ & $\begin{array}{l}\text { peluang terdeteksi } \\
\text { sedang }\end{array}$ \\
\hline 4 & $\begin{array}{l}\text { - } \quad \text { kerusakan tinggi } \\
\text { - } \quad \text { konsumen merasakan penurunan } \\
\text { kualitas dan melebihi batas toleransi }\end{array}$ & $\begin{array}{l}\text { terjadi } 1 \text { pada tiap } 3 \text { kali } \\
\text { dilakukan aktivitas }\end{array}$ & $\begin{array}{l}\text { peluang terdeteksi } \\
\text { kecil }\end{array}$ \\
\hline 5 & $\begin{array}{l}\text { - } \quad \text { kerusakan sangat tinggi } \\
\text { - } \quad \text { konsumen tidak akan menerima } \\
\text { produk }\end{array}$ & $\begin{array}{l}\text { terjadi pada tiap kali } \\
\text { dilakukan aktivitas }\end{array}$ & tidak dapat dideteksi \\
\hline
\end{tabular}

Sumber: Chrysler (1995); Gaspersz (2002); Kartikasari dan Romadhon (2019); ${ }^{*}=$ modifikasi oleh peneliti

\section{Risk Priority Number (RPN)}

Tahap ini akan bertujuan menentukan prioritas risiko penanganan dan transportasi ikan tuna (Thunnus sp) di PPP Pondokdadap hingga ke konsumen. Tujuan ini dapat diperoleh dengan menghitung nilai Risk Priority Number (RPN). Nilai RPN berasal dari pengolahan nilai SOD sebagai berikut:

$$
\mathrm{RPN}=(\mathrm{S}) \times(0) \times(\mathrm{D})
$$

Keterangan:

RPN = Nilai risiko prioritas

$\mathrm{S} \quad=$ tingkat keparahan yang ditimbulkan

$\mathrm{O}=$ frekuensi terjadinya risiko

$\mathrm{D} \quad$ = tingkat deteksi probabilitas penyebab kegagalan

Nilai RPN bertujuan mengetahui risiko kritis dan digunakan untuk melakukan mitigasi pada risiko yang mendapatkan nilai tinggi (Teng et al. 2006). Tahap dalam menentukan mitigasi risiko yang pertama adalah menghitung skor risiko dan RPN, selanjutnya melakukan perangkingan terhadap skor RPN. Setelah didapatkan perankingan maka akan mendapatkan risiko prioritas dan segera dilakukan mengembangkan rencana mitigasi risiko tersebut (Wahyuni dan Sumarmi 2018). Penentuan risiko prioritas dilakukan dengan melihat nilai kritis pada nilai RPN melalui rumus sebagai berikut:

$$
\text { Nilai kritis }=\left(\sum \mathrm{RPN}\right) /\left(\sum \text { Risiko }\right)
$$

Keterangan:

Nilai Kritis = Nilai batas bawah penentuan rangking RPN

$\sum \mathrm{RPN}=$ Jumlah total nilai RPN

$\sum$ Risiko = Jumlah risiko 


\section{HASIL DAN PEMBAHASAN}

\section{Analisis Sensori}

Metode sensori dalam tahap ini menggunakan uji organoleptik sesuai dengan Badan Standarisasi Nasional dengan SNI 01-2729.1-2006 yang menggunakan parameter penampakkan luar, kelenturan daging, keadaan mata, daging perut, bau, serta warna insang. Sampel ikan yang diambil adalah ikan tuna dengan bobot $\geq 20 \mathrm{~kg}$ yang dipisahkan berdasarkan jenis. Menurut SNI 01-2729.1 (2006) ikan segar akan dinyatakan cacat apabila nilai pengamatan organoleptiknya kurang dari 7. Hasil penelitian menunjukkan bahwa untuk kategori ikan tuna $\geq 20 \mathrm{~kg}$, ikan tuna cacat dengan jumlah tertinggi berada pada proses penanganan di TPI dengan jenis tuna albakor. Daftar ikan tuna cacat berdasarkan proses dan jenisnya disajikan pada Tabel 2.

Tabel 2 Data tuna cacat bobot $\geq 20 \mathrm{Kg}$

\begin{tabular}{cllcc}
\hline No. & \multicolumn{1}{c}{ Nama Proses } & \multicolumn{1}{c}{ Jenis Ikan } & Jumlah Sampel & Jumlah Cacat \\
\hline 1 & \multirow{2}{*}{ Pembongkaran } & Sirip Kuning & 50 & 3 \\
2 & Albakor & 50 & 20 \\
3 & & Mata Besar & 50 & 10 \\
4 & & Sirip Kuning & 50 & 3 \\
5 & Penanganan di TPI & Albakor & 50 & 25 \\
6 & & Mata Besar & 50 & 10 \\
7 & & Sirip Kuning & 50 & 3 \\
8 & Penanganan di Gudang & Albakor & 50 & 13 \\
9 & & Mata Besar & 50 & 8 \\
10 & & Sirip Kuning & 50 & 8 \\
11 & Proses Pengiriman & Albakor & 50 & 8 \\
12 & & Mata Besar & 50 & 114 \\
\hline
\end{tabular}

Tabel 2 menunjukkan bahwa terdapat 4 proses dalam ikan dengan bobot $\geq 20 \mathrm{~kg}$. Proses yang dilakukan mulai dari pembongkaran hingga pengiriman. Dalam setiap proses diambil 50 sampel ikan berdasarkan jenis tuna yang tertangkap yaitu tuna sirip kuning, tuna albakor dan tuna mata besar. Dari data tersebut menunjukkan jumlah cacat terbesar terdapat pada jenis ikan tuna albakor saat proses pasca pembongkaran sampai dengan penanganan di TPI. Selanjutnya diikuti oleh tuna albakor saat proses pembongkaran. Rata-rata ikan tuna yang memiliki jumlah cacat tinggi terdapat pada ikan tuna albakor dan yang terendah pada ikan tuna sirip kuning. Hal ini terjadi karena ikan tuna sirip kuning memiliki harga yang lebih mahal dari ikan albakor, sehingga penanganan ikan tuna sirip kuning lebih diutamakan.

\section{Peta Kendali $p$}

Cacat produk dalam penelitian ini adalah proporsi jumlah cacat pada ikan tuna dengan berat $\geq 20$ kg. Peta kendali p memiliki Upper Control Limit (UCL) dan Lower Control Limit (LCL) sebagai nilai pengendalian. Proses akan dinyatakan diluar kendali apabila proporsi cacat ikan tuna melebihi nilai UCL ataupun LCL. Hasil penelitian menunjukkan bahwa untuk ikan tuna $\geq 20 \mathrm{~kg}$, proporsi cacat yang berada diluar kendali terjadi pada proses nomor 5. Proses tersebut adalah aktivitas penanganan pasca pembongkaran sampai dengan penanganan di TPI dengan jenis ikan tuna albakor. Peta kendali p tuna $\geq 20 \mathrm{~kg}$ disajikan pada Gambar 1 . 


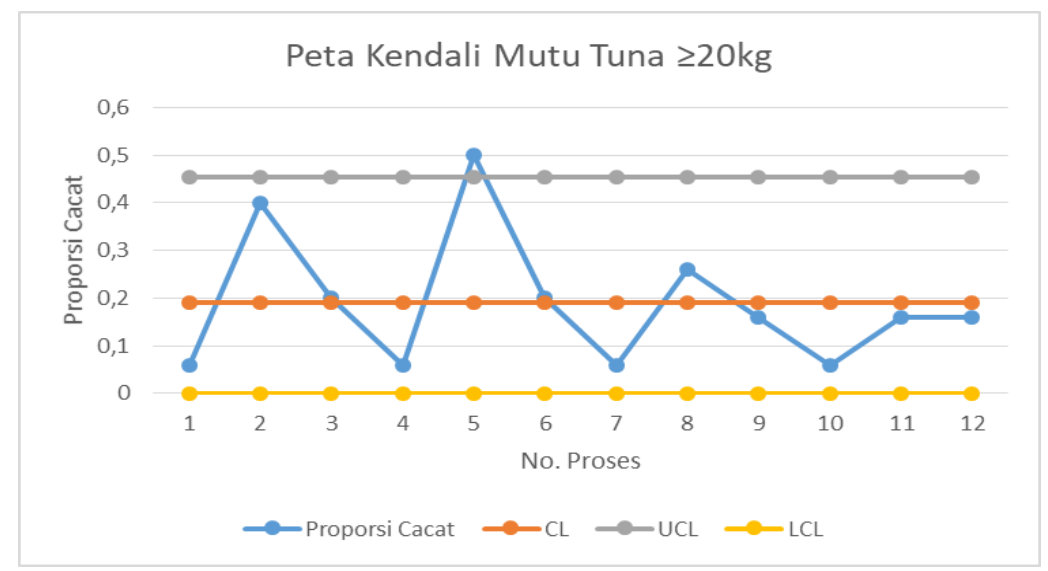

Gambar 1 Peta kendali p tuna $\geq 20 \mathrm{Kg}$

Gambar 1 menunjukkan bahwa garis Center Line (CL) atau garis tengah memiliki nilai 0,190. Nilai UCL atau batas atas memiliki nilai sebesar 0,453 dan untuk nilai LCL atau batas bawah adalah 0,000. Kegiatan dapat dikatakan terkendali jika nilai proporsi cacat tidak melebihi nilai UCL dan LCL. Pada gambar 1 terlihat bahwa terdapat satu nilai yang melebihi UCL. Nilai tersebut berada pada proses 5 yang merupakan aktivitas penanganan pasca pembongkaran sampai dengan penanganan di TPI dengan jenis ikan tuna albakor. Hal ini dikarenakan aktivitas penanganan ikan tuna albakor yang dilakukan di PPP Pondokdadap selama pasca pembongkaran sampai dengan penanganan di TPI oleh pelaku produksi dilakukan dengan kurang baik, sehingga berakibat pada proses yang berada diluar pengendalian.

\section{Diagram Sebab-Akibat/Fishbone Diagram}

Data pengamatan langsung dan wawancara yang dilakukan selama proses penanganan dan transportasi ikan tuna di PPP Pondokdadap, diperoleh beberapa faktor yang mempengaruhi penurunan mutu ikan tuna albakor dengan berat $\geq 20 \mathrm{~kg}$ yang menyebabkan proses berada diluar kendali. Faktorfaktor tersebut dilihat dari 4 aspek yaitu man, machine, method dan material dan disajikan pada Gambar 2.

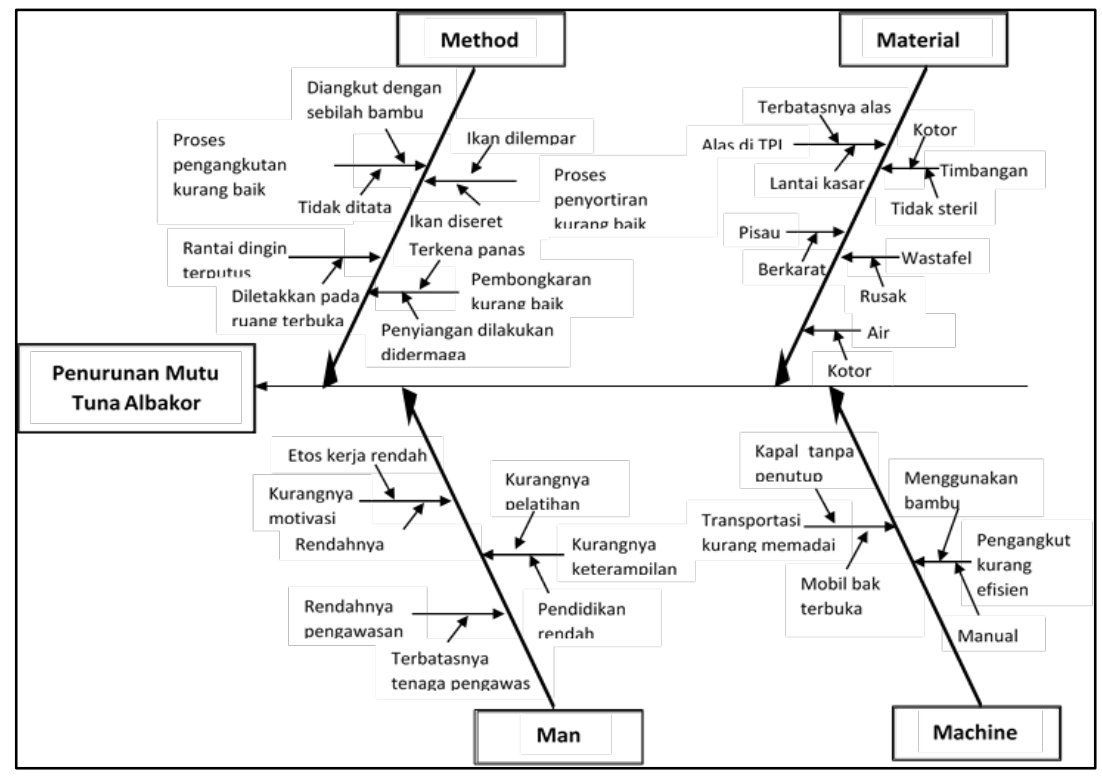

Gambar 2 Diagram fishbone faktor penyebab penurunan mutu diluar kendali tuna albakor $\geq 20 \mathrm{~kg}$ 


\section{Faktor Man}

Man (manusia) dalam kegiatan ini terdiri dari anak buah kapal (ABK), kuli panggul dan petugas pelabuhan. Pada proses ini, ABK akan bertugas mengeluarkan ikan dari palka dan meletakkan di atas dek. Proses selanjutnya akan dilanjutkan oleh kuli panggul. Tugas kuli panggul adalah mengangkut ikan dari dek kapal menuju TPI untuk ditimbang kemudian di sortir menurut jenis dan ukuran. Segala kegiatan ini akan diawasi oleh petugas pelabuhan. Petugas pelabuhan terbagi menjadi 2 tim, tim pertama akan memantau proses bongkar muat kapal sampai dengan selesai sortir di TPI. Tim pertama juga bertugas melakukan pendataan hasil tangkapan pada setiap kapal yang melakukan bongkar. Tim kedua bertugas melakukan inspeksi mutu pada setiap ikan hasil tangkapan.

Proses pembongkaran oleh ABK dilakukan dengan mengandalkan pengalaman dan kebiasaan yang sudah turun temurun. Hal ini dikarenakan tingkat pendidikan nelayan di PPP Pondokdadap yang tergolong rendah dan $\mathrm{ABK}$ belum peduli dengan dampak menurunnya mutu ikan terhadap nilai jual. Proses pembongkaran dilakukan dengan tidak memperhatikan kebersihan tubuh ataupun keadaan sekitar. Hal ini tampak pada sebagian besar ABK yang melakukan bongkar dengan tangan kotor dan pakaian yang kurang bersih. Selain itu, masih banyak ABK yang makan, merokok bahkan meludah saat proses pembongkaran berlangsung. Tidak hanya ABK, kondisi kuli panggul juga dapat dikatakan tidak bersih. Sebelum memegang ikan, kuli panggul tidak mencuci tangan ataupun memakai sarung tangan yang seharusnya. Hal ini terjadi karena kurangnya kesadaran dan pembekalan terhadap kuli panggul. Selain itu, kuli panggul juga mengatakan bahwa mereka harus cepat dalam melakukan pengangkutan agar ikan dapat segera terjual. Namun, hal ini perlu diimbangi dengan cara penanganan yang baik agar tidak menurunkan mutu sehingga harga jual menjadi sangat kecil. Selain karena faktor ABK dan kuli panggul, petugas pelabuhan juga berperan penting dalam penerapan proses penanganan dan transportasi ikan yang baik. Pengawasan dari pihak pelabuhan yang kurang maksimal menyebabkan hal ini terus terjadi. Tidak adanya sanksi untuk para pelaku usaha yang melakukan penanganan dan transportasi yang tidak sesuai prosedur menjadi salah satu alasan kejadian ini terus berulang. Selain itu, kurangnya tenaga pengawas menyebabkan pengawasan tidak dapat dilakukan secara merata.

\section{Faktor Method}

Method (metode) adalah cara pelaku usaha atau man (manusia) dalam melakukan penanganan dan transportasi ikan hasil tangkapan (Rahayu 2019). Metode penanganan yang dilakukan oleh pelaku usaha di PPP Pondokdadap yang terdiri dari ABK dan kuli panggul dapat dikatakan kurang baik. Kekurangan tersebut diantaranya terputusnya rantai dingin, hal ini dikarenakan ikan tuna albakor diletakkan pada ruang terbuka di atas dek kapal tanpa diberi pelindung ataupun es. Selain itu proses pembongkaran juga dilakukan di dermaga dan terkena panas matahari langsung. Penurunan suhu ikan akan berpengaruh terhadap penurunan mutu, karena bakteri akan lebih cepat berkembang dan terjadi proses pembusukan.

Pengangkutan ikan dari dek menuju TPI oleh kuli panggul juga dilakukan dengan kurang baik. Ikan tuna albakor akan diangkut menuju TPI dengan sebilah bambu dan ikan dalam keadaan terbalik. Hal ini menyebabkan ikan yang besarnya melebihi tinggi kuli panggul akan terseret pada lantai kasar dan terkena genangan air di lantai. Pengangkutan seperti ini akan menyebabkan ikan tergores dan cacat pada tubuh. Proses selanjutnya yaitu penyortiran di TPI, ikan akan dipisahkan berdasarkan ukuran dan jenis dengan cara diseret. Setelah itu ikan akan dilempar ke tempat yang sesuai dengan kelompok kriterianya. Hal ini menyebabkan banyak ikan yang tergores dan mengalami cacat tubuh. Saat ikan diseret, tubuh ikan akan tergores karena mengenai lantai kasar, selain itu ikan juga akan terkena genangan air yang dapat menambah bakteri sehingga proses pembusukan semakin cepat terjadi.

\section{Faktor Machine}

Machine merupakan sarana dan teknologi yang digunakan, yaitu terkait dengan teknologi pengangkut dan transportasi yang digunakan. Pengangkutan ikan tuna albakor di PPP Pondokdadap 
masih menggunakan teknologi yang sangat sederhana. Pengangkutan ini dilakukan dengan alat bantu sebilah bambu. Ikan tuna albakor akan diikat pada bambu dengan posisi terbalik dan kemudian akan dipanggul oleh dua orang kuli panggul. Peralatan yang sangat sederhana ini akan menyebabkan proses pengangkutan menjadi kurang efisien dari segi waktu dan tenaga. Selain itu, proses ini memberikan dampak buruk pada kualitas ikan tuna albakor karena ikan akan terseret-seret.

Transportasi yang digunakan di PPP Pondokdadap untuk ikan tuna albakor juga dinilai masih kurang memadai. Hal ini dikarenakan masih ada kapal tanpa penutup yang beroperasi dalam penangkapan ikan tuna. Kapal tanpa penutup ini berdampak pada kualitas ikan karena ikan akan langsung terkena panas matahari. Selain itu, setelah sampai di TPI ikan yang telah selesai disortir akan dimasukkan ke mobil bak terbuka untuk selanjutnya dibawa ke gudang penyimpanan. Mobil bak terbuka tanpa diberi penutup dan es ini akan menambah penurunan kualitas ikan tuna albakor. Pada prinsipnya ikan harus berada pada suhu rendah dan bila tidak dalam cold storage, es harus terus diberikan hingga suhu ikan mencapai $0^{\circ} \mathrm{C}$ (Deni 2015).

\section{Faktor Material}

Material adalah alat dan bahan yang digunakan selama proses penanganan dan transportasi ikan tuna albakor di PPP Pondokdadap. Alat dan bahan ini yaitu air, timbangan, pisau, alas di TPI dan wastafel. Material yang digunakan saat proses penanganan dan transportasi ikan tuna albakor di PPP Pondokdadap beberapa ada yang tidak steril, terbatas sampai dengan tidak dapat digunakan. Air yang digunakan ABK untuk mencuci ikan saat di dermaga adalah air laut. Dimana air laut tersebut telah tercemar dengan tumpahan minyak, sampah dan partikel berbahaya lainnya. Selain itu, timbangan ikan yang digunakan di PPP Pondokdadap tidak dicuci dengan bersih setelah digunakan dan akan digunakan lagi pada keesokan harinya. Pisau yang digunakan ABK untuk membersihkan insang dan isi perut ikan tuna albakor juga beberapa telah berkarat. Alas halus di TPI yang digunakan untuk meletakkan ikan tuna juga terbatas, ikan tuna yang diberi alas halus hanya untuk ikan tuna jenis yellowfin tuna dan bigeye tuna yang berukuran besar. Hal ini terjadi karena terbatasnya alas dan harga jual tuna albakor yang lebih rendah dibanding jenis tuna lainnya. Ikan albakor akan diberi alas jika hasil tangkapan yellowfin dan bigeye tidak dalam jumlah besar. Selain itu, wastafel pada TPI ada yang tidak berfungsi dan menghambat para pelaku usaha untuk melakukan cuci tangan sebelum menyentuh ikan. Beberapa material tersebut akan memberikan dampak pada penurunan kualitas ikan tuna albakor dan mempengaruhi nilai jualnya.

\section{Risk Assesment}

Risk assesment atau penilaian risiko merupakan langkah penting yang harus diperhatikan dalam menentukan prioritas risiko pada proses penanganan dan transportasi ikan tuna di PPP Pondokdadap. Hal ini bertujuan untuk mendapatkan besaran nilai risiko secara rinci yang dilihat dari tingkat kerusakan (severity), frekuensi kejadian (occurance) dan tingkat deteksi (detection). Risk assesment bobot $\geq 20 \mathrm{~kg}$ dapat dilihat pada Tabel 3 .

Tabel 3 Risk assesment tuna albakor bobot $\geq 20 \mathrm{~kg}$

\begin{tabular}{cllccc}
\hline \multirow{2}{*}{ Proses } & Failure mode & Effect & \multicolumn{3}{c}{ Risk Assesment } \\
\cline { 3 - 5 } & & $\begin{array}{c}\text { Severity } \\
(S)\end{array}$ & $\begin{array}{c}\text { Occurrence } \\
(O)\end{array}$ & $\begin{array}{c}\text { Detection } \\
(D)\end{array}$ \\
\hline $\begin{array}{l}\text { Pembongkaran } \\
\text { ikan dari kapal }\end{array}$ & $\begin{array}{l}\text { Insang dan isi } \\
\text { perut } \\
\text { dibersihkan di } \\
\text { atas kapal saat } \\
\text { di dermaga }\end{array}$ & $\begin{array}{l}\text { penurunan mutu ikan } \\
\text { secara signifikan }\end{array}$ & 5 & 5 & 1 \\
& & & & \\
\end{tabular}




\begin{tabular}{|c|c|c|c|c|c|}
\hline \multirow{8}{*}{ Proses } & \multirow[b]{2}{*}{ Failure mode } & \multirow[b]{2}{*}{ Effect } & \multicolumn{3}{|c|}{ Risk Assesment } \\
\hline & & & $\begin{array}{l}\text { Severity } \\
(S)\end{array}$ & $\begin{array}{l}\text { Occurrence } \\
(O)\end{array}$ & $\begin{array}{l}\text { Detection } \\
\text { (D) }\end{array}$ \\
\hline & $\begin{array}{l}\text { Pisau yang } \\
\text { digunakan } \\
\text { berkarat }\end{array}$ & ikan terkontaminasi & 3 & 4 & 2 \\
\hline & $\begin{array}{l}\text { Terbatasnya } \\
\text { tenaga kerja }\end{array}$ & $\begin{array}{l}\text { proses pembersihan } \\
\text { lama }\end{array}$ & 3 & 4 & 2 \\
\hline & $\begin{array}{l}\text { Ikan dicuci } \\
\text { dengan air } \\
\text { kotor }\end{array}$ & $\begin{array}{l}\text { ikan terkontaminasi } \\
\text { bakteri }\end{array}$ & 4 & 4 & 2 \\
\hline & $\begin{array}{l}\text { Ikan yang telah } \\
\text { dibersihkan } \\
\text { dilempar di dek } \\
\text { yang disediakan }\end{array}$ & $\begin{array}{l}\text { ikan cacat daging dan } \\
\text { tekstur }\end{array}$ & 5 & 4 & 1 \\
\hline & $\begin{array}{l}\text { Ikan diletakkan } \\
\text { di dek tanpa } \\
\text { alas }\end{array}$ & $\begin{array}{l}\text { ikan cacat karena } \\
\text { tergores alas yang kasar }\end{array}$ & 4 & 5 & 1 \\
\hline & $\begin{array}{l}\text { Ikan diangkut } \\
\text { ke } \\
\text { penimbangan } \\
\text { dengan bambu }\end{array}$ & $\begin{array}{l}\text { penurunan mutu karena } \\
\text { ikan terseret dan } \\
\text { terkena air kotor }\end{array}$ & 5 & 5 & 1 \\
\hline $\begin{array}{l}\text { Penimbangan } \\
\text { Ikan di TPI }\end{array}$ & $\begin{array}{l}\text { Timbangan } \\
\text { kotor }\end{array}$ & ikan terkontaminasi & 3 & 4 & 2 \\
\hline \multirow[t]{4}{*}{$\begin{array}{l}\text { Penyortiran } \\
\text { ikan di TPI }\end{array}$} & Ikan di lempar & $\begin{array}{l}\text { tubuh ikan tergores dan } \\
\text { menimbulkan cacat }\end{array}$ & 5 & 5 & 2 \\
\hline & $\begin{array}{l}\text { Ikan diletakkan } \\
\text { di lantai tanpa } \\
\text { alas }\end{array}$ & $\begin{array}{l}\text { tubuh ikan tergores } \\
\text { lantai yang kasar }\end{array}$ & 5 & 5 & 2 \\
\hline & $\begin{array}{l}\text { Wastafel tidak } \\
\text { berfungsi }\end{array}$ & $\begin{array}{l}\text { ikan terkontaminasi } \\
\text { karena pekerja tidak } \\
\text { mencuci tangan dahulu }\end{array}$ & 2 & 3 & 3 \\
\hline & $\begin{array}{l}\text { Terdapat } \\
\text { genangan air } \\
\text { disekitar } \\
\text { tempat } \\
\text { penyortiran }\end{array}$ & $\begin{array}{l}\text { ikan terkontaminasi } \\
\text { dengan air kotor } \\
\text { disekitarnya }\end{array}$ & 4 & 3 & 2 \\
\hline \multirow[t]{4}{*}{$\begin{array}{l}\text { Pengangkutan } \\
\text { ikan ke moda } \\
\text { transportasi }\end{array}$} & $\begin{array}{l}\text { Moda } \\
\text { transportasi } \\
\text { dengan mobil } \\
\text { pick up terbuka }\end{array}$ & $\begin{array}{l}\text { ikan terkena langsung } \\
\text { oleh cahaya matahari } \\
\text { ikan terkontaminasi } \\
\text { debu }\end{array}$ & 5 & 4 & 2 \\
\hline & $\begin{array}{l}\text { Ikan di seret } \\
\text { mendekati } \\
\text { mobil pick up }\end{array}$ & tubuh ikan tergores & 5 & 5 & 1 \\
\hline & $\begin{array}{l}\text { Ikan } \\
\text { dilemparkan ke } \\
\text { atas mobil pick } \\
\text { up }\end{array}$ & tubuh ikan tergores & 5 & 5 & 1 \\
\hline & $\begin{array}{l}\text { Ikan tidak } \\
\text { diberi es }\end{array}$ & $\begin{array}{l}\text { bakteri cepat } \\
\text { berkembang }\end{array}$ & 5 & 4 & 1 \\
\hline
\end{tabular}


Tabel 3 menunjukkan terdapat 4 proses dalam penanganan dan transportasi ikan tuna albakor dengan berat $\geq 20 \mathrm{~kg}$ saat kegiatan pasca pembongkaran sampai dengan penanganan di TPI. Pada proses pembongkaran ikan dari kapal, nilai severity tertinggi terjadi pada mode kegagalan saat insang dan isi perut ikan dibersihkan di atas kapal ketika tiba di dermaga, ikan dilempar ke atas dek dan ikan diangkut ke penimbangan dengan bambu. Mode kegagalan ini memiliki nilai severity yang besar karena menyebabkan kerusakan yang tinggi dan berakibat pada cepatnya proses penurunan mutu pada tahap awal. Sehingga memperbesar potensi kerusakan produk yang akan disadari oleh konsumen dan terjadi penolakan. Nilai occurance tertinggi berada pada mode kegagalan ketika insang dan isi perut ikan dibersihkan di atas kapal saat tiba di dermaga, ikan diletakkan di dek tanpa alas dan ikan diangkut ke penimbangan dengan bambu. Nilai occurance pada tahap ini memiliki nilai terbesar karena terjadi pada setiap dilakukan aktivitas. Nilai detection tertinggi berada pada mode kegagalan pisau yang digunakan berkarat, terbatasnya tenaga kerja dan ikan dicuci dengan air kotor. Hal ini terjadi karena kejadian tersebut dapat dideteksi dengan peluang tinggi, namun bukan berarti dapat selalu terdeteksi karena ada beberapa ABK yang menggunakan pisau tidak berkarat, tercukupinya tenaga kerja saat hasil tangkapan rendah dan pencucian ikan dengan air bersih yang tersisa.

Proses penimbangan ikan di TPI hanya memiliki satu mode kegagalan yaitu timbangan yang kotor dan nilai tertinggi berada pada nilai occurance. Hal ini karena pemakaian timbangan yang kotor terjadi 1 pada tiap 3 kali dilakukan aktivitas. Proses ketiga yaitu penyortiran ikan di TPI, nilai severity dan occurance tertinggi berada pada mode kegagalan saat ikan di lempar dan ikan diletakkan di lantai tanpa alas. Mode kegagalan ini memiliki nilai severity yang tinggi karena dampak penurunan mutu dari aktivitas tersebut dapat dikatakan besar dan akan disadari oleh konsumen. Tingginya nilai occurance pada mode kegagalan ini karena pelemparan ikan dan peletakkan ikan tanpa alas terjadi pada setiap dilakukan aktivitas. Nilai detection tertinggi pada proses ini berada pada mode kegagalan wastafel tidak berfungsi. Hal ini terjadi karena kerusakan wastafel sulit di deteksi dan tidak dapat diketahui kapan akan rusak atau berfungsi kembali.

Proses terakhir dalam aktivitas penanganan dan transportasi ikan tuna albakor pasca pembongkaran sampai dengan penanganan di TPI adalah pengangkutan ikan ke moda transportasi. Nilai severity tertinggi berada pada semua mode kegagalan, yaitu moda transportasi yang menggunakan mobil bak terbuka (pick up), ikan di seret mendekati mobil pick up, ikan dilemparkan ke atas mobil pick up dan ikan tidak diberi es. Nilai severity pada aktivitas ini sangat tinggi karena dapat memberikan dampak cacat tubuh dan penurunan mutu dengan cepat karena ikan tidak berada pada suhu rendah. Nilai occurance tertinggi berada pada mode kegagalan ikan di seret mendekati mobil pick up dan saat ikan dilemparkan ke atas mobil pick up. Nilai occurance pada tahap ini sangat tinggi karena terjadi pada setiap dilakukan aktivitas. Nilai detection tertinggi berada pada mode kegagalan moda transportasi dengan mobil bak terbuka. Hal ini terjadi karena tidak semua ikan tuna albakor akan diangkut dengan mobil bak terbuka, bila jumlahnya mencapai 200 ekor pada saat sekali bongkar, maka akan langsung diangkut dengan truk berpendingin.

\section{Risk Priority Number (RPN)}

RPN bertujuan untuk mendapatkan prioritas risiko yang dilihat dari perhitungan skor SOD. Risiko prioritas akan didapatkan dengan perangkingan nilai RPN sehingga mendapatkan risiko kritis dan segera dilakukan rencana pengembangan mitigasi. Risk priority number tuna albakor $\geq 20 \mathrm{~kg}$ disajikan pada Tabel 4 . 
Tabel 4 Risk priority number tuna albakor $\geq 20 \mathrm{~kg}$

\begin{tabular}{|c|c|c|c|c|c|c|}
\hline \multirow{2}{*}{ Proses } & \multirow{2}{*}{ Failure mode } & \multirow{2}{*}{ Effect } & \multicolumn{3}{|c|}{ Risk Assesment } & \multirow{2}{*}{$R P N$} \\
\hline & & & $S$ & $O$ & $\bar{D}$ & \\
\hline \multirow[t]{7}{*}{$\begin{array}{l}\text { Pembongkaran } \\
\text { Ikan dari } \\
\text { Kapal }\end{array}$} & $\begin{array}{l}\text { Insang dan isi perut } \\
\text { dibersihkan di atas kapal } \\
\text { saat di dermaga }\end{array}$ & $\begin{array}{l}\text { penurunan mutu ikan secara } \\
\text { signifikan }\end{array}$ & 5 & 5 & 1 & 25 \\
\hline & $\begin{array}{l}\text { Pisau yang digunakan } \\
\text { berkarat }\end{array}$ & ikan terkontaminasi & 3 & 4 & 2 & 24 \\
\hline & Terbatasnya tenaga kerja & proses pembersihan lama & 3 & 4 & 2 & 24 \\
\hline & Ikan dicuci dengan air kotor & ikan terkontaminasi bakteri & 4 & 4 & 2 & 32 \\
\hline & $\begin{array}{l}\text { Ikan yang telah dibersihkan } \\
\text { dilempar di dek yang } \\
\text { disediakan }\end{array}$ & ikan cacat daging dan tekstur & 5 & 4 & 1 & 20 \\
\hline & $\begin{array}{l}\text { Ikan diletakkan di dek tanpa } \\
\text { alas }\end{array}$ & $\begin{array}{l}\text { ikan cacat karena tergores } \\
\text { alas yang kasar }\end{array}$ & 4 & 5 & 1 & 20 \\
\hline & $\begin{array}{l}\text { ikan diangkut ke } \\
\text { penimbangan dengan bambu }\end{array}$ & $\begin{array}{l}\text { penurunan mutu karena ikan } \\
\text { terseret dan terkena air kotor }\end{array}$ & 5 & 5 & 1 & 25 \\
\hline $\begin{array}{l}\text { Penimbangan } \\
\text { Ikan di TPI }\end{array}$ & Timbangan kotor & ikan terkontaminasi & 3 & 4 & 2 & 24 \\
\hline \multirow[t]{4}{*}{$\begin{array}{l}\text { Penyortiran } \\
\text { Ikan di TPI }\end{array}$} & Ikan di lempar & $\begin{array}{l}\text { tubuh ikan tergores dan } \\
\text { menimbulkan cacat }\end{array}$ & 5 & 5 & 2 & 50 \\
\hline & $\begin{array}{l}\text { Ikan diletakkan di lantai } \\
\text { tanpa alas }\end{array}$ & $\begin{array}{l}\text { tubuh ikan tergores lantai } \\
\text { yang kasar }\end{array}$ & 5 & 5 & 2 & 50 \\
\hline & Wastafel tidak berfungsi & $\begin{array}{l}\text { ikan terkontaminasi karena } \\
\text { pekerja tidak mencuci tangan } \\
\text { dahulu }\end{array}$ & 2 & 3 & 3 & 18 \\
\hline & $\begin{array}{l}\text { Terdapat genangan air } \\
\text { disekitar tempat penyortiran }\end{array}$ & $\begin{array}{l}\text { ikan terkontaminasi dengan } \\
\text { air kotor disekitarnya }\end{array}$ & 4 & 3 & 2 & 24 \\
\hline \multirow[t]{4}{*}{$\begin{array}{l}\text { Pengangkutan } \\
\text { Ikan ke Moda } \\
\text { Transportasi }\end{array}$} & $\begin{array}{l}\text { Moda transportasi dengan } \\
\text { mobil pick up terbuka }\end{array}$ & $\begin{array}{l}\text { ikan terkena langsung oleh } \\
\text { cahaya matahari } \\
\text { ikan terkontaminasi debu }\end{array}$ & 5 & 4 & 2 & 40 \\
\hline & $\begin{array}{l}\text { Ikan di seret mendekati } \\
\text { mobil pick up }\end{array}$ & tubuh ikan tergores & 5 & 5 & 1 & 25 \\
\hline & $\begin{array}{l}\text { Ikan dilemparkan ke atas } \\
\text { mobil pick up }\end{array}$ & tubuh ikan tergores & 5 & 5 & 1 & 25 \\
\hline & Ikan tidak diberi es & bakteri cepat berkembang & 5 & 4 & 1 & 20 \\
\hline
\end{tabular}

Tabel 4 menunjukkan rentang nilai RPN berkisar antara 18 sampai dengan 50. Nilai RPN pada tiap-tiap mode kegagalan telah diketahui maka langkah selanjutnya adalah menentukan risiko prioritas (risiko kritis). Risiko prioritas akan didapatkan dengan analisis melalui nilai kritis. Nilai kritis merupakan batas bawah nilai RPN yang akan menjadi patokan penentuan risiko prioritas, maka yang termasuk dalam risiko prioritas adalah mode kegagalan yang memiliki nilai RPN di atas nilai kritis. Nilai kritis ditentukan dari rata-rata RPN dari seluruh risiko dengan perhitungan sebagai berikut:

$$
\begin{aligned}
\text { Nilai kritis } & =\frac{\sum \mathrm{RPN}}{\sum \text { Risiko }}=\frac{446}{16} \\
& =27,86
\end{aligned}
$$


Perhitungan nilai kritis menujukkan nilai 27,86, maka yang termasuk dalam risiko prioritas adalah risiko atau mode kegagalan yang memiliki nilai di atas nilai kritis yaitu terdapat 4 mode kegagalan antara lain pencucian ikan dengan air kotor, ikan dilempar saat penyortiran, ikan diletakkan di lantai tanpa alas dan penggunaan moda transportasi dengan mobil bak terbuka (Tabel 5).

Tabel 5 Risiko prioritas penanganan dan transportasi tuna albakor $\geq 20 \mathrm{~kg}$

\begin{tabular}{cllc}
\hline Rangking & \multicolumn{1}{c}{ Proses } & \multicolumn{1}{c}{ Failure Mode } & RPN \\
\hline 1 & Penyortiran ikan di TPI & Ikan dilempar & 50 \\
2 & Penyortiran ikan di TPI & Ikan diletakkan di lantai tanpa alas & 50 \\
3 & Pengangkutan ikan ke moda & moda transportasi dengan mobil bak & 40 \\
4 & transportasi & terbuka (pick up) & 32 \\
\hline
\end{tabular}

\section{KESIMPULAN DAN SARAN}

Berdasarkan hasil penelitian yang telah dilakukan dapat disimpulkan bahwa terdapat 4 mode kegagalan (failure mode) yang menjadi risiko prioritas dalam penanganan dan transportasi ikan tuna albakor $220 \mathrm{~kg}$ di PPP Pondokdadap. Mode kegagalan tersebut yaitu pencucian ikan dengan air kotor, ikan dilempar saat penyortiran, ikan diletakkan di lantai tanpa alas dan penggunaan moda transportasi dengan mobil bak terbuka.

\section{DAFTAR PUSTAKA}

Andiyanto S., Sutrisno A., Punuhsingon C. 2017. Penerapan Metode FMEA (Failure Mode and Effect Analysis) Untuk Kuantifikasi Dan Pencegahan Resiko Akibat Terjadinya Lean Waste. Jurnal Online Poros Teknik Mesin. 6(1): 45-57.

Arsyad A. G., Ferdinant P. F., Ekawati R. 2017. Analisis Peta Kendali p yang distandarisasi dalam Proses Produksi Regulator Set Fujiyama (Studi Kasus: PT. XYZ). Jurnal Teknik Industri. 5(1): 86-92.

Badan Standarisasi Nasional. 2006. SNI Ikan Segar No. SNI No. 01-2729.1-2006. Badan Standarisasi Nasional, Jakarta. 137 hlm.

Chrysler C. 1995. Potential Failure and Effects Analysis (FMEA) Reference Manual 2nd Edition. Ford Motor Company. $68 \mathrm{hlm}$.

Deni S. 2015. Karakteristik Mutu Ikan Selama Penanganan pada kapal KM. Cakalang. Jurnal Ilmiah agribisnis dan Perikanan. 8(2): 72-80.

Furqan I. 2017. Penanganan Hasil Tangkapan Tuna di Pelabuhan Perikanan Pantai Pondokdadap untuk Memenuhi Standar Pasar Ekspor. [Tesis]. Bogor (ID). Institut Pertanian Bogor. 89 hlm.

Gaspersz V. 2002. Pedoman Implementasi Program Six Sigma. Jakarta: Gramedia Pustaka Utama.

Kartikasari V., Romadhon, H. 2019. Analisis Pengendalian dan Perbaikan Kualitas Proses Pengalengan Ikan Tuna Menggunakan Metode Failure Mode And Effect Analysis (FMEA) dan Fault Tree Analysis (FTA) Studi kasus di PT XXX Jawa Timur. Journal of Industrial View. 1(1): 1-10.

Khomah I., Rahayu E. S. 2015. Aplikasi Peta Kendali p Sebagai Pengendalian Kualitas Karet di PTPN IX Batujamus/Kerjoarum. Jurnal AGRARIS. 1(1): 12-24.

Laismina A. N., Monotulu L. A. D., Mentang F. 2014. Kajian Mutu Ikan Tuna (Thunnus albacares) Segar di Pasar Bersehati Kelurahan Calaca Manado. Jurnal Media Teknologi Hasil Perikanan. 2(2): 1519. 
Menteri Kelautan dan Perikanan Republik Indonesia. 2013. No. 52A/KEPMEN/KP/2013 Tentang Persyaratan Jaminan Mutu dan Keamanan Hasil Perikanan pada Proses Produksi, Pengolahan dan Distribusi. Jakarta. $30 \mathrm{hlm}$.

Murnawan H., Mustofa. 2014. Perencanaan Produktivitas Kerja dari Hasil Evaluasi Produktivitas dengan Metode Fishbone di Perusahaan Percetakan Kemasan PT X. Jurnal Teknik Industri HEURISTIC. 11(1): 27-46.

Nurani T. W. 2010. Model Pengelolaan Perikanan: Suatu Kajian Pendekatan Sistem. Bogor (ID): Institut Pertanian Bogor.

Perdana R. P., Yuliawati E. 2014. Integrasi Metode FMEA dan Topsis Untuk Menganalisis Risiko Kecelakaan Pada Proses Frame and Fork Welding. Jurnal Spektrum Industri. 12 (1): 43-52.

[PPP] Pelabuhan Perikanan Pantai Pondokdadap. 2020. Laporan Monitoring Pelabuhan Perikanan Panttai (PPP) Laporan Bulanan Tahun 2016-2020. Malang.

Purwitasari A. 2011. Manajemen Risiko Operasional Pada Pemasaran Benih Ikan Patin PT Mitra Mina Nusantara di Kabupaten Bogor, Jawa Barat. [Skripsi]. Bogor (ID): Institut Pertanian Bogor. 120 hlm.

Rahayu D. 2019. Produksi bersih dalam penanganan hasil tangkapan dan komponen sisa pada pendaratan ikan di Pelabuhan Perikanan Samudera Nizam Zachman [skripsi]. Bogor (ID): Institut Pertanian Bogor. $38 \mathrm{hlm}$

Rahmah A. 2010. Sanitasi dan Higienitas Serta Dampaknya Terhadap Mutu Ikan dan Pengguna Pelabuhan Perikanan Pantai Lampulo Banda Aceh. [Skripsi]. Bogor. Fakultas Perikanan dan Ilmu Kelautan. Institut Pertanian Bogor. 133 hlm.

Syafitri M., Fahrul. 2016. Studi Kualitas Ikan Segar Secara Organoleptik yang Dipasarkan Di Kabupaten Jeneponto. Jurnal IPTEKS PSP. 3(6): 544-552.

Teng S. G., Ho S. M., Shumar D, Liu P.C. 2006, Implementing FMEA In A Collaborative Supply Chain Enviroment", International Journal Of Quality \& Reliability Management. 23(2), 179-196.

Tunjungsari F. D. 2009. Analisis Perilaku Konsumen Terhadap Pembelian Ikan Kakap Merah di Pasar Tradisional Kota Surakarta. [Skripsi]. Surakarta (ID): Universitas Sebelas Maret.

Wahyuni H. C., dan W. Sumarmi. 2018. Pengukuran Risiko Keamanan Pangan pada Sistem Rantai Pasok Ikan Segar. Jurnal Teknik Industri. 13(1): 37-44.

Yusra M., Hamzah A., Syahnur S. 2014. Analisis Permintaan Tuna Sirip Kuning (Yellowfin) Indonesia di Pasar Jepang. Jurnal Ilmu Ekonomi. 2(2): 72-81. 